\title{
MEDIA SOSIAL SEBAGAI STRATEGI KOMUNIKASI POLITIK
}

\author{
Nur Alfiyani \\ Institut Agama Islam Negeri Manado, Manado, Indonesia \\ nur.alfiyani@iain-manado.ac.id
}

\begin{abstract}
Communication strategy in politics is one of the keys to success in gathering votes. This research aims to determine the political communication strategies used by candidates to obtain votes. This research is a type of qualitative research with descriptive analysis approach. Data obtained through interviews and literature. The result of the study indicate that now, as time goes by and the rapidly development of communication technology, the emergence of new media or social media caused a shift in the campaign. Many used new media during the campaigns to attract as many people as possible and to vote. For example, someone who has a Twitter account and has 150 thousand followers has the power to propagate, because those who read the twit are very much. The 150 thousand readers are more than the readers of the Pikiran Rakyat newspaper, which are only about 75 thousand people. Mudzakkir Ali Djamil Candidates for the Makassar City DPRD use interpersonal communication techniques by utilizing social media, this is because he is aware of the important role of the media to make the public opinion.
\end{abstract}

Keywords: Legislative Candidates, Political Communication, Social Media.

Abstrak. Strategi komunikasi dalam politik merupakan salah satu kunci keberhasilan dalam mengumpulkan suara. Penelitian ini bertujuan untuk mengetahui strategi komunikasi politik yang digunakan oleh caleg untuk dapat memperoleh suara. Penelitian ini merupakan jenis penelitian kualitatif dengan pendekatan deskriptif analisis. Data diperoleh melalui wawancara dan studi pustaka. Hasil penelitian menunjukkan bahwa sekarang, seiring berjalannya waktu dan perkembangan tekonologi komunikasi yang juga begitu pesat, munculnya media-media baru atau yang dikenal dengan media sosial menyebabkan terjadinya pergeseran dalam kampanye. Banyak yang menggunakan media sosial pada saat kampanye untuk menarik massa sebanyak-banyaknya dan untuk memilih. Sebagai contoh, seseorang yang memiliki account Twitter dan memiliki 150 ribu follower memiliki kekuatan untuk mempropaganda, karena yang membaca twit-nya sangat banyak. Pembaca 150 ribu itu lebih banyak dari jumlah pembaca surat kabar Pikiran Rakyat yang hanya sekitar 75 ribu orang. Mudzakkir Ali Djamil Caleg DPRD Kota Makassar menggunakan teknik komunikasi interpersonal dengan memanfaatkan mesia sosial, hal ini dikarenakan beliau menyadari akan peran penting media dalam membentuk opini publik.

Kata Kunci: Calon Legislatif. Komunikasi Politik, Media Sosial, 


\section{Pendahuluan}

Pemilihan umum (Pemilu) merupakan sarana demokrasi yang menjadi ajang bagi kedaulatan rakyat. Dalam negara demokratis, pemilu yang notabene merupakan cerminan suara rakyat menjadi penentu bagi keberlangsungan sebuah negara untuk menentukan nasib dan tujuan sebuah bangsa. Suara-suara inilah yang akan diwadahi oleh partai politik-partai politik yang mengikuti pemilu menjadi wujud wakil-wakil rakyat.

Adanya banyak partai politik yang mengikuti pemilu legislatif 2014, sebagai konsekuensi sistem multipartai yang diterapkan di Indonesia. Terdapatnya banyak partai politik juga berdampak pada ketatnya kompetisi antar partai politik dalam menggaet suara pemilih untuk memperebutkan kursi. Keberhasilan seorang caleg dalam perolehan suara, membuktikan betapa besarnya dukungan dan kepercayaan rakyat terhadap orang tersebut. Guna memenangkan kompetisi di ajang pemilu, para kontestan saling bersaing satu sama lain dengan menerapkan berbagai strategi komunikasi politik yang jitu.

Komunikasi politik yang dilakukan tentunya menyesuaikan dengan sistem politik yang ada di Indonesia. Oleh karena itu, sistem politik mau tidak mau turut mempengaruhi dan dipengaruhi oleh komunikasi yang dilakukan oleh partai politik. Almond dan Powell menempatkan komunikasi politik sebagai suatu fungsi politik bersama-sama dengan fungsi artikulasi, agregasi, sosialisasi dan rekrutmen yang terdapat dalam suatu sistem politik.

Strategi komunikasi politik pada dasarnya merupakan langkah-langkah dalam melakukan komunikasi politik berkaitan dengan pembuatan, penyebarluasan, penerimaan, dan dampak-dampak informasi berkontent politik, baik melalui interaksi antar manusia maupun media massa.

Tujuan komunikasi politik sangat terkait dengan pesan politik yang disampaikan komunikator politik. Sesuai dengan tujuan komunikasi, maka tujuan komunikasi politik itu adakalanya sekedar penyampaian informasi politik, pembentukan citra politik, pembentukan publik opinion (pendapat umum). Selanjutnya komunikasi politik bertujuan menarik simpatik khalayak dalam rangka meningkatkan partisipasi politik saat menjelang pemilihan umum. Menang atau kalahnya seorang caleg sangat ditentukan oleh strategi komunikasi yang dilakukan.

Tulisan ini akan membahas mengenai strategi komunikasi politik dalam pemilu legislatif DPRD Kota Makassar periode 2014-2019 untuk mengetahui sejauh mana peran strategi komunikasi politik dalam memenangkan seseorang.

Wawancara dilakukan terhadap caleg DPRD Kota Makassar yang menang dan kalah dari daerah pemilihan yang sama, yaitu Mudzakkir Ali Djamil, ST Calon Anggota DPRD Kota Makassar periode 2014-2019 Dapil I dari partai PKS dengan No urut 1 dan Mukhlis Yusuf. ST dari partai yang sama dengan no urut 3 dengan menjelaskan mengenai teori dan teknik komunikasi politik yang digunakan oleh kedua belah pihak.

Tujuan penelitian ini untuk mengetahui proses strategi komunikasi politik yang dilakukan oleh Mudzakkir Ali Djamil dan Mukhlis Yusuf. ST dalam menghadapi Pemilu legislatif Kota Makassar tahun 2014. 


\section{Metode Penelitian}

Dasar penelitian yang penulis gunakan dalam penelitian ini adalah metodologi kualitatif dengan pendekatan deskriptif analisis yaitu metode untuk pengukuran yang cermat terhadap fenomena sosial tertentu. Pada penelitian ini penulis menggunakan tipe penelitian deskriptif. Tipe penelitian yang menggambarkan secara mendalam tentang strategi komunikasi politik caleg DPRD Kota Makassar dalam pemenangan Pemilu.

Sumber Data diperoleh dalam berbagai bentuk, seperti rekaman hasil wawancara dan foto kegiatan di lapangan. Penulis selain turun ke lapangan, juga melakukan telaah pustaka yakni mengumpulkan data dari buku, jurnal, koran, dan sumber informasi lainnya yang erat kaitannya dengan masalah penelitian.

Data dan informasi yang telah dikumpulkan dari informan akan diolah dan dianalisa secara kualitatif. Langkah yang digunakan dalam analisis data adalah sebagai berikut: reduksi data, sajian data, dan verifikasi data.

\section{Strategi Komunikasi Politik}

Strategi komunikasi dalam politik merupakan salah satu kunci keberhasilan sebuah Partai politik dalam memenangkan pemilu. Kampanye politik adalah bentuk aplikasi komunikasi politik yang dilakukan seseorang, sekelompok orang atau organisasi politik untuk membentuk dan membina citra dan opini publik yang positif, agar terpilih dalam suatu pemilihan pemilu, pemilukada dan pilpres. $^{1}$

1 Anwar Arifin, Komunikasi Politik: Paradigma - Teori - Aplikasi - Strategi dan Komunikasi Politik Indonesia, (Jakarta: PT. Balai Pustaka, 2003), h. 11
Beberapa bentuk atau jenis seni dan bentuk aplikasi (penerapan) komunikasi politik yang sudah lama dikenal dan dilakukan oleh para politikus atau aktivis politik, antara lain retorika politik, agitasi politik, propaganda politik, lobi politik, dan tindakan politik yang dapat dilakukan dalam kegiatan politik yang terorganisasi seperti: public relation post politic, pemasaran politik dan kampanye politik.

Semua bentuk komunikasi politik itu berkaitan dengan pembentukan citra dan opini publik yang positif. Hal itu dapat berkaitan dengan upaya memenangkan pemilu agar dapat meraih kekuasaan dan kedudukan politik di lembaga legislatif atau eksekutif sehingga dapat membuat kebijakan politik yang sesuai dengan visi misi dan program politik para komunikator politik terutama para politikus dan partai politiknya.

1. Retorika Politik

Retorika pada dasarnya
menggunakan lambang untuk
mengidentifikasikan pembicara
dengan pendengar melalui pidato
sedang pidato merupakan konsep
yang sama pentingnya dengan
retorika sebagai simbolisme. Dengan
berpidato kepada khalayak secara
terbuka akan berkembang wacana
publik dan berlangsung proses
persuasi. Itulah sebabnya Dan
Nimmo menyebutkan pidato adalah
negoisasi dengan retorika politik
akan tercipta masyarakat dengan
negoisasi (konflik dan konsensus)
yang terus berlangsung. ${ }^{2}$

2 Dan Nimmo, Komunikasi Politik: Komunikator, Pesan dan Media (Edisi Terjemahan oleh Tjun Surjaman), (Bandung: PT. Remaja Rosdakarya, 1989), h. 140 
Aristoteles dalam karyanya retorica membagi retorika politik dalam 3 jenis yaitu: retorika diliberitif, retorika forensik, retorika demonstratif.

2. Agitasi politik

Agitasi menurut Blumer dimulai dengan cara membuat kontradiksi dalam masyarakat dan menggerakkan khalayak untuk menentang kenyataan hidup yang dialami selama ini (penuh ketidakpastian dan penuh penderitaan) dengan tujuan menimbulkan kegelisahan dikalangan massa. ${ }^{3}$

Kemudian rakyat digerakkan untuk mendukung gagasan baru atau ideologi baru dengan menciptakan keadaan yang baru. Agitasi sering berkonotasi negatif karena sifatnya yang menghasut, mengancam, menggelisahkan membangkitkan rasa tidak puas dikalangan khalayak dan mendorong adanya pemberontakan.

3. Propaganda politik

Propaganda merupakan yang sudah lama dikenal penggunaannya dalam bidang politik, meskipun pada awalnya digunakan sebagai bentuk kegiatan keagamaan (agama katolik). Propaganda politik dapat merupakan kegiatan komunikasi politik yang dilakukan secara terencana dan sistematik, menggunakan sugesti untuk tujuan mempengaruhi seseorang atau kelompok orang, khalayak atau komunitas yang lebih besar agar melaksanakan atau menganut suatu ide, atau kegiatan tertentu dengan

3 Herbert Blumer, Symbolic Interactionism: Perspektif and Method, (New Jersy: Harper and Row, 1969), h. 71 kesadarannya sendiri tanpa merasa dipaksa atau terpaksa.

Selanjutnya, ada beberapa tipe propaganda diantaranya seperti propaganda terang terangan, propaganda disengaja, dan propaganda yang tidak disengaja. Di negara demokrasi kegiatan propaganda politik sangat tidak disukai, bahkan ditolak dengan cara mengembangkan kegiatan yang lain seperti public relation politik dan penerangan politik.

4. Lobi politik

Lobi merupakan salah satu bentuk seni dan teknik berkomunikasi yang banyak sekali diaplikasikan dalam kegiatan politik. Lobi politik dan partai politik, merupakan forum pembicaraan politik dalam persfektif atau paradigma interaksional dalam komunikasi politik diterapkan dalam bentuk komunikasi antar personal atau tatap muka yang bersifat dialogis.

Jika lobi politik bersifat informal (tidak ada tata tertib) maka rapat politik, persidangan politik, atau forum musyawarah politik justru bersifat sangat formal atau resmi. Dalam lobi politik pengaruh pribadi sangat penting. Dalam hal itu kompetensi, penguasaan masalah, jabatan dan kepribadian politikus sangat berpengaruh.

5. Tindakan politik

Tindakan yang dapat dipandang sebagai komunikasi dalam paradigma pragmatis merupakan juga bentuk seni dan teknik dalam berkomunikasi yang selalu digunakan dalam kegiatan politik. Dengan demikian, lobi politik, retorika politik dan kampanye politik dapat juga disebut 
sebagai tindakan politik yang merupakan salah satu bentuk tindakan politik.

Tindakan politik dalam peristiwa komunikasi politik bertujuan untuk membangun citra politik bagi khalayak, yaitu gambaran mengenai realitas politik yang memiliki makna

Strategi dan komunikasi politik adalah suatu keseluruhan keputusan kondisional tentang tindakan yang akan dijalankan saat ini, guna mencapai tujuan politik pada masa depan. Keputusan strategis yang tepat bagi komunikator politik adalah (1) Merawat ketokohan, (2) Memantapkan kelembagaan politik, (3) Menciptakan kebersamaan dan (4) Membangun konsensus. ${ }^{4}$

1. Ketokohan dan kelembagaan

Ketika komunikasi politik berlangsung yang berpengaruh bukan hanya pesan politik saja melainkan siapa tokoh politik atau tokoh aktivis dan profesional dari lembaga mana yang menyampaikan pesan politik tersebut. Dengan kata lain, ketokohan seseorang merupakan komunikator politik dan lembaga politik yang mendukungnya sangat menentukan berhasil atau tidaknya komunikasi politik dalam menentukan sasaran dan tujuannya, dalam hal ini merawat ketokohan dan memantapkan kelembagaan.

2. Menciptakan kebersamaan

Langkah strategis kedua yang harus dilakukan untuk mencapai tujuan komunikasi politik adalah menciptakan kebersamaan antara politikus dan rakyat dengan cara mengenal khalayak dan menyusun pesan yang homofili. Hal itu diperlukan agar komunikator politik dapat melakukan empati.

${ }^{4}$ Anwar Arifin, Op.Cit, h. 46
Hemofili dan empati adalah salah satu syarat untuk membangun dan merawat ketokohan bagi politikus, aktivis, dan profesional sebagai komunikator politik. Untuk menciptakan hemofili dan melakukan empati melalui persamaan kepentingan tersebut, komunikator politik harus terlebih dahulu mengenal, mengerti dan memahami daya tangkal serta daya serap khalayak, baik yang bersifat pisikologis maupun yang bersifat sosiokultural.

Hal itu memerlukan berbagai aktifitas seperti penjajakan dan survei atau pembuktian. Dengan cara memahami khalayak, menyusun pesan persuasi, menetapkan metode, dan memilah milih media.

3. Membangun konsensus

Langkah strategi ketiga yang harus dilakukan untuk mencapai komunikasi politik yaitu membangun konsensus baik antara para politikus dalam salah satu partai politik maupun perantara politikus dari partai yang berbeda. Hal itu pada umumnya terjadi baik pada rapat dan persidangan maupun dalam lobi, dengan menggunakan model komunikasi interaktif sesuai dengan paradigma interaksional.

Dalam paradigma internasional tersebut semua pihak yang berkomunikasi atau berinteraksi memiliki posisi yang sama dan sederajat, sehingga tercipta suasana yang dialogis. Komunikasi interaksional dikenal sebagai komunikasi yang manusiawi karena semua pihak diangkat derajatnya ke posisi yang mulia.

Suasana dialogis harus dibangun melalui penciptaan kebersamaan atau hemofili dengan melakukan empati. Hal itu dimaksudkan agar semua pihak memiliki rasa saling memiliki sehingga dapat berpartisipasi aktif. Dalam membangun konsensus tersebut seni 
berkompromi, dan bersedia membuka diri merupakan salah satu strategi yang harus dipahami oleh seorang politikus dalam melakukan komunikasi politik.

\section{Keperkasaan Social Media dalam membentuk opini publik}

Social media merupakan bagian dari teknologi yang tidak bisa dihindari. Artinya, teknologi itu akan datang dan kita tidak bisa menghindar. Misalnya ada sisi negatifnya lalu kita tidak boleh menggunakan itu, tentu tidak bisa. Teknologi merupakan keniscayaan sejarah, dengan segala konsekuensinya. Teknologi akan selalu datang. Ketika kita menghambatnya, berarti kita telah menghambat perkembangan dan pengetahuan manusia. Selama manusia masih mampu berpikir dan berinovasi, maka teknologi baru akan terus bermunculan.

Setiap hari, setiap jam, bahkan setiap detik teknologi baru tercipta. Tak jauh berbeda dengan perkembangan media yang kini memasuki era new media atau sering dikatakan sebagai media masa depan. New media memiliki konsep cukup luas dan perkembangannya pun cukup pesat, dilihat dari perkembangan komputer, internet, handphone, smartphone, hingga tablet. Dengan perkembangan ini, banyak hal turut berubah, seperti kebiasaan, pola hidup, hingga cara berkomunikasi. Perubahan jelas berdampak positif maupun negatif.

Perubahan pola komunikasi yang terjadi setelah tumbuhnya social media cukup besar. Dulu, konsep dasar komunikasi pada media adalah adanya komunikator yang sering dijabarkan sebagai media massa, kelompok besar atau organisasi, sementara komunikan adalah masyarakat yang hanya menerima dan memberikan respon atau feedback tertunda. Kini, konsep itu berubah drastis.
Saat ini, individu dapat menjadi komunikator untuk khalayak luas. Seorang komunikan pun dapat berubah menjadi komunikator ketika ia dapat mengungkapkan atau mendorong bahkan mempropaganda masyarakat lainnya.

Sekarang yang namanya audiens atau komunikan bisa sekaligus menjadi komunikator. Artinya, saat ini publik dapat menjadi komunikator, sedangkan dulu komunikator adalah media, institusiinstitusi besar, dan organisasi-organisasi besar. Jadi, masyarakat dulu semi pasif atau bahkan pasif yang hanya menerima, kalaupun berkomentar sifatnya terbatas dan tertunda. Sekarang, masyarakat pengguna media konvensional pun kalah waktunya dibandingkan pengguna media modern semacam social media. Gadget lebih sering digunakan ketimbang menonton televisi atau membaca Koran.

Seseorang yang membuka sosial media bisa membaca pesan yang disampaikan, forward pesan, komentar, bahkan membuat status atau twit baru, dan disebarkan. Ini berarti orang tersebut sudah menjadi komunikator. Jadi, public menjadi komunikator untuk public yang lain.

Pengaruh Penggunaan Media online Twitter, facebook, blogger, youtube dan aneka jejaring sosial dalam Kampanye Pemilihan umum ABSTRAKSI "We cannot not communicate", berangkat dari aksioma komunikasi ini, teknologi yang menjadi media dalam komunikasi terus berkembang dari hari ke hari. Perkembangan teknologi dalam komunikasi ini sendiri juga membawa pengaruh dalam kehidupan manusia baik dalam hal ekonomi, sosial, budaya dan juga politik.

Bidang politik cukup banyak terpengaruh oleh teknologi komunikasi sendiri. Komunikasi sangat penting dan diperlukan dalam politik dan merupakan 
salah satu bagian dari kegiatan politik sendiri. Kampanye politik sendiri juga sering mempergunakan media komunikasi di dalamnya. Media online jejaring sosial sebagai salah satu produk teknologi komunikasi cukup banyak dipergunakan dalam kampanye pemilu Konsep McLuhan yang menyatakan bahwa teknologi adalah media menjadi konsep dasar yang menjadi landasan dalam analisis kasus ini. Dari konsep McLuhan ini turun ke dalam beberapa teori yang memiliki kaitan dan juga dapat menjadi pisau analisis dalam berbagai kasus yang ada dalam bidang politik.

Hasil diskusi dan kesimpulan adalah bahwa teknologi komunikasi yang selalu berkembang menyebabkan pengaruh pada bidang politik melalui kegiatan kampanye yang kini dikembangakan melalui media baru dan dapat terlihat adanya technological deternism yang ada di tengah masyarakat sebab banyaknya orang yang begitu ketergantungan dengan fungsi teknologi sehingga kehidupan sangat dikuasai oleh teknologi.

Sebagai makhluk sosial, manusia tak akan pernah bisa hidup sendiri dan hal ini juga membenarkan salah satu aksimoma dari komunikasi bahwa "we cannot not communicate." 5 Benar sekali bahwa manusia tak bisa untuk tidak berkomunikasi. Komunikasi ini baik komunikasi secara verbal maupun non verbal. Komunikasi sendiri merupakan sebuah proses menyampaian pesan dari sender kepada receiver melalui media.

Berangkat dari aksioma yang satu ini, teknologi pun berkembang dengan begitu cepat tanpa kita sadari sepenuhnya. Seiring berjalannya waktu, teknologi berkembang dengan cukup

5 Brent D Ruben, Communication Year Books 2, (New Jersy: ICA, 2006), h. 213 pesat dan rmenimbulkan bermunculannya begitu banyak media baru yang memberikan dampak pada kehidupan sosial masyarakat, “...New media technologies impact our life culture by offering new lifestyles, creating new jobs and eliminating others, demanding regulations and presenting unique new social issues ... ."6

Seperti Facebook, MySpace, Linked In atau pun Twitter dengan hampir jutaan masyarakat dunia telah bergabung menjadi satu dalam berbagai banyaknya jenis dari sosial media set. Setiap jenis social media seperti Facebook, MySpace dan lain sebagainya memiliki masingmasing yang berbeda satu dengan yang lainnya.

Dengan begitu banyaknya jenis dan pengguna di setiap sosial media yang kini berkembang membuat banyak pula yang dampak dan dengan secara senggaja memanfaatkan sosial media untuk dapat mencapai tujuan yang hendak dicapai hampir dalam segala aspek kehidupan. ${ }^{7}$ Salah satu bidang yang cukup banyak sangat bergantung dengan teknologi komunikasi adalah bidang politik. Karena pada bidang politik ini komunikasi politik menjadi hal yang sangat penting.

Salah satu bentuk kegiatan politik yang diketahui banyak masyarakat luas adalah kampanye politik. Dalam hal ini kampanye sendiri sudah terbagi dalam beberapa kategori seperti kampanye legistatif, kampanye capres dan juga kampanye dalam pemilu kepala daerah dan lain sebagainya. Yang juga sangat

6 J. Rose Straubhaa \& Davenport L, Media Now: Understanding Media, Culture, and Technology (seventh edition), (Boston: Wadsworth, 2012), h. 96

7 Michael M Mirabito, Morgenstern, Barbara L, The New Communications Technologies: Applications, Policy, and Impact, (USA: Focal Press, 2004), h. 23 
menarik untuk diamati adalah pergeseran bentuk kampanye politik yang dilakukan oleh para calon dalam kampanye.

Sebelum berkembanganya teknologi komunikasi masih sangat banyak dijumpai bagaimana cara kampanye dengan memasang umbulumbul besar, spanduk-spanduk diseluruh badan jalan, berbagai poster juga baliho memenuhi seluruh sudut kota yang sebenarnya cukup begitu banyak memiliki dampak baik positif dan negative di dalamnya.

Sekarang, seiring berjalannya waktu, dan perkembangan tekonologi komunikasi yang juga begitu pesat, seperti yang telah dijelaskan sebelumnya tentang munculnya media-media baru menjadikan terjadinya pergeseran dalam kampanye tersebut. Banyak yang menggunakan media baru dalam kampanye untuk menarik massa sebanyak-banyaknya dan untuk memilih.

Beberapa peserta telah mulai melakukan cara untuk menarik perhatian massa untuk memilih mereka. Berbagai cara mulai dari cara-cara lama seperti penggunaan baliho, menyebarkan berbagai poster juga umbul-umbul, muncul diberbagai acara dengan berbagai pencitraan.

Beberapa tim sukses peserta juga memanfaatkan sosial media sebagai sarana untuk menarik perhatian massa. Hampir semua sosial media yang ada juga dimanfaatkan salah satunya adalah forum jejaring sosial dan media online. Sosial media telah sangat banyak mempengaruhi kehidupan manusia, termasuk di bidang politik yang juga terpengaruh dengan keberadaan sosial media. Dalam bidang politik sendiri yang di dalamnya juga terdapat komunikasi politik yang membuat masyarakat untuk dapat terpengaruh memilih calon untuk mendapatkan sebuah kekuasaan. Berawal dari konsep dasar dari McLuhan bahwa media adalah teknologi dan teknologi adalah perpanjangan dari tangan manusia. ${ }^{8}$ Banyak manfaat yang diberikan oleh penggunaan teknologi, namun sering kali kita terjebak bahwa teknologi hanya sebuah alat elektronik yang sangat canggih. Menurut McLuhan, semua media untuk sarana menyampaikan pesan dari sender kepada receiver merupakan teknologi yang menjadi perpanjangan tangan manusia. Tak hanya itu saja, teori difusi inovasi juga menjadi salah satu landasan teori.

Dalam teori ini, disebutkan bahwa: "Diffusion is the process by which an innovation is communicated through certain channels over time among the members of a social system. It is a special type of communication, in that the messages are. concerned with new ideas. Communication is a process in which participants create and share information with one another in order to reach a mutual understanding. This definition implies that communication is a process of convergence (or divergence) as two or more individuals exchange information in order to move toward each other(or apart) in the meanings that they ascribe to certain events. We thinkof communication as a two-way process of convergence, rather thanas a one-way, linear act in which one individual seeks to transfer a message to another." 9

Konsep teori lainnya adalah Teori Matematika Komunikasi. Teori yang dikemukakan oleh Shanon dan Weaver ini menjelaskan tentang bagaimana teori Informasi yang melihat adanya

8 Marshall McLuhan, Understanding Media: The Extension of man, (New York: McGrawHill, 1964), h. 75

9 Rogers Everett M, Communication Technology: The New Media in Society, (New York: The Free Press, 2003), h. 28 
redundancy pada pesan, keterbatasan dalam akurasi transmisi (channel capacity), dan keterbatasan jumlah informasi dalam channel (throughput) "The fundamental problem of communication is that of reproducing at one point either exactly or approximately a message selected at another point. Frequently the messages have meaning; that is they refer to or are correlated according to some system with certain physical or conceptual entities. These semantic aspects of communication are irrelevant to the engineering problem. The significant aspect is that the actual message is one selected from a set of possible messages. The system must be designed to operate for each possible selection, not just the one which will actually be chosen since this is unknown at the time of design." 10

Konsep ini pun dapat menjadi pisau analasis dalam pembahasan mengenai penggunaan media online dalam kampanye. Selain teori-teori masih ada juga berbagai deskripsi dari sosial networking sites dan juga twitter sendiri menurut Grant. Tak hanya itu, social networking dan pemilihan umum ini juga menunjukkan sebuah tanda-tanda dari techonology determinism yang merupakan gejala atau pun tanda dimana masyarakat telah dipengaruhi oleh teknologi dalam berbagai aspek kehidupan salah satunya adalah di bidang politik.

Teknologi telah mengalami sebuah perubahan dan inovasi untuk menyesuaiakan dengan kebutuhan masyarakat yang ada. Inovasi ini berasal dari berbagai faktor dan pihak yang nantinya teknologi ini juga bisa menjadi perpanjangan tangan manusia dan

10 Shannon and $\mathrm{W}$ Weaver, The Mathematical Theory of Cmmunication. (Urbana University of Illinois Press, 1957), h. 91 membantu memenuhi dan menyelesaikan masalah manusia. ${ }^{11}$ Salah satu produk dari media baru yang banyak berkembang sekarang ini adalah media sosial.

Media sosial sebagai salah satu media baru benar-benar dimanfaatkan semaksimal mungkin oleh masyarakat. Definisi dari sosial media adalah sebagai berikut "... social network sites as webbased services that allow individuals to (1) construct a public or semi-public profile within a bounded system, (2) articulate a list of other users with whom they share a connection, (3) view and traverse their list of connections and those made by others within the system. The nature and nomenclature of these connections may vary from site to site ..."12

Beberapa saran yang dapat diberikan dalam penggunaan media komunikasi dalam hal ini sebagai sosial network sites adalah:

1. Admin dari setiap account tiap calon memiliki pemahaman mengenai teknologi komunikasi jadi tidak akan terjadi hal- hal yang tidak diinginkan ataupun juga humen eror karena admin dari account tersebut masih pada tataran user bukan expert.

2. Memilih jam-jam yang tepat untuk mempost isu, seperti coffee break time, jam makan siang bukan pada saat jam kerja atau pun jam pulang kantor, untuk meningkatkan awareness para followers untuk membaca isi dari postingan.

11 Williams dan Sawyer, Using Information Technology: A Practical Introduction to Computers and Communication, (London: Career Education, 2003), h. 10

12 D. M Boyd, 7 Ellison N. B, Social Network sites: Definitions, History, and Scholarship, (Journal of Computer-Mediated Communications: Sosial Media, 2007), h.2 
3. Dalam informasi yang disebarkan melalui twitter merupakan hal-hal yang bersifat fakta, persuasive bukan hanya kata-kata 'rayuan gombal' agar para followers memilih.

4. Memperhatikan kembali efisiensi dan intensitas postingan agar followers tidak menganggap hal tersebut sebgai sesuatu hal yang mengganggu atau spam dan pada akhirnya tujuan dari kampanye tidak tercapai.

\section{Teknik Komunikasi}

Banyak penelitian menyinggung kekuatan media, sehingga muncul teoriteori yang memaparkan betapa media dapat berfungsi sebagai sarana edukasi, propaganda, informasi hingga menghibur. Dengan hadirnya new media ini semakin mebuat dunia media semakin beragam.

Seseorang yang memiliki account Twitter dan memiliki follower 150 ribu misalnya, ia memiliki kekuatan untuk mempropaganda, karena yang membaca twit-nya sangat banyak. Pembaca 150 ribu itu lebih banyak dari jumlah pembaca surat kabar Pikiran Rakyat yang hanya sekitar 75 ribu orang. Jadi, sekarang tak hanya media massa yang bisa meruntuhkan suatu Negara, tapi individu pun bisa melakukannya dengan bantuan social media.

Kedahsyatan terpaan sosial media dikarenakan komunikasi interpersonal. Dalam komunikasi, yang dapat memberikan perubahan sikap paling besar adalah komunikasi interpersonal. Riset-riset komunikasi mengatakan, pengaruh komunikasi interpersonal sangat besar terhadap seseorang, ampuhnya komunikasi interpersonal disadari sejak lama. Masalahnya, dulu dibutuhkan waktu lama untuk melakukan komunikasi interpersonal kepada banyak orang, sehingga komunikasi massa dianggap lebih mudah. Tapi kini, komunikasi interpersonal lebih mudah dan cepat dilakukan dengan social media. Semua orang dapat menjadi komunikator layaknya media massa tanpa harus memiliki banyak uang, tidak seperti fenomena sebelumnya ketika pemilik media massa adalah para konglomerat atau pemodal besar. Individu dalam dunia seperti sekarang bisa menjadi apa saja terkait media.

Ketika seseorang memiliki follower yang banyak, lalu dia mengupload video dan gambar disertai narasi dan penjelasan, maka dia otomatis telah memiliki media. Itulah yang dinamakan media konvergensi atau teknologi konvergensi, dimana terjadi penggabungan atau pengintegrasian media-media yang ada untuk digunakan dan diarahkan kedalam satu titik tujuan. Konvergensi biasanya merujuk pada perkembangan teknologi komunikasi digital yang dimungkinkan dengan adanya konvergensi jaringan.

Indonesia merupakan salah satu negara yang memiliki kecepatan luar biasa dalam pertumbuhan teknologi dan new media. Dalam hal social media, Indonesia menjadi salah satu pengguna terbanyak di dunia. Perkembangannya merasuk hingga pelosok nusantara. Penggunanya berbagai kalangan.

Fenomena penyebaran pesan singkat atau broadcast melalui aplikasi "messenger" di telepon genggam maupun media sosial yang isi pesan itu belum tentu benar dan tidak bisa dipertanggungjawabkan akurasinya. Namun tanpa disadari atau tidak, masyarakat yang meneruskan broadcast tersebut membuat mereka menjadi bagian dari agen propagandis.

Mudzakkir Ali Djamil, ST Calon Anggota DPRD Kota Makassar periode 
2014-2019 Dapil I (Makassar, Ujung Pandang, Rappocini) dari partai PKS dengan No urut 1. Mudzakkir Ali Djamil memenangkan pemilu legislative dengan meraup suara sebanyak 3.395. Beliau pernah menempuh kuliah di Jurusan Teknik Elektro Universitas Hasanuddin Makassar dan juga merupakan ketua umum BKPRMI (Badan Komunikasi Pemuda Remaja Masjid Indonesia) kota Makassar periode 2014-2018.

Beliau menyadari betapa pentingnya peranan strategi komunikasi politik. Untuk mendapatkan perolehan suara mayoritas dalam Pemilu legislative tahun 2014, maka beliau melakukan strategi komunikasi dengan langkahlangkah sebagai berikut: blusukan, advokasi kebutuhan warga, dan penggunaan media (social media). Perencanaan meliputi:

a Pendanaan/budgeting,

b Pembentukan team kampanye, slogan kampanye, serta target sasaran.

Pengorganisasian meliputi:

a Komunikasi politik antar partai politik pendukung,

b Komunikasi politik dengan elemen masyarakat dengan cara mengadvokasi kepentingan masyarakat dalam bentuk Perda

c Kontroling/pengawasan peran pemerintah terhadap proses pembangunan untuk masyarakat. Untuk mengatasi hambatan komunikasi, maka Mudzakkir Ali Djamil melakukan model komunikasi Andap Asor, artinya urusan massa dimasingmasing partai politik dan elemen diserahkan kepada masing-masing elite. Massa sendiri yang menilai sosok Mudzakkir Ali Djamils. Sedangkan evaluasi dilakukan untuk mengukur sejauh mana strategi komunikasi berdampak kepada masyarakat.
Dari hasil penelitian dapat dilihat bahwa Mudzakkir Ali Djamil telah merencanakan strategi komunikasi politik jauh sebelum Pilkada berlangsung, hal ini terlihat dari matangnya pembentukan team, media kampanye, dan model komunikasi. Pengorganisasian strategi komunikasi dilakukan secara maksimal dengan menggerakkan seluruh komponen baik di partai maupun masyarakat.

Penggunaan alat kampanye berupa baliho yang dipasang disetiap kelurahan, sticker, dan yang terbanyak adalah brosur (profil dan kiprah dari Mudzakkir Ali Djamil, ST). Sedangkan untuk mengatasi hambatan komunikasi dilakukan secara pribadi dengan menggunakan sosial media berupa facebook, twitter, path, whatsapp, dan blackberry massanger serta dengan menggunakan strategi blsusukan (door to door), karena menurut beliau masyarakat di kedua segmen tersebut merupakan masyarakat yang harus digarap dengan menggunakan dua strategi yang berbeda untuk memperoleh suara maksimal.

Selain itu Mudzakkir Ali Djamil juga melakukan evaluasi, artinya apakah strategi komunikasi politik menimbulkan efek di masyarakat. Pengalaman ini telah diperoleh beliau mengingat ini kedua kalinya beliau terpilih menjadi caleg DPRD propinsi Makassar. Beliau juga merupakan salah satu anggota dewan di periode sebelumnya yang memperoleh penghargaan, berkinerja baik, pernah memenangkan BTAQ, serta sering menjadi narasumber dari media sehingga semakin mempermulus jalan beliau dalam memenangkan pemilu legislatif periode 2014-2019.

Berikutnya adalah Mukhlis Yusuf. ST, Calon Anggota DPRD Kota Makassar periode 2014-2019 Dapil I dari partai PKS dengan No urut 3. Mukhlis Yusuf 
merupakan salah seorang Caleg DPRD yang tidak memenangkan Pemilu Legislatif.

Strategi komunikasi politk yang beliau lakukan relatif sama dengan saingan beliau Mudzakkir Ali Djamil mengingat beliau juga berasal dari partai yang sama dengan Mudzakkir Ali Djamil, hanya saja beliau kurang aktif dalam memanfaatkan media soaial sebagai wadah komunikasi politik dalam mengumpulkan suara masyarakat, beberapa pemenang pemilu legislatif juga ternyata aktif di berbagai organisasi sehingga mereka telah terlebih dahulu mensosialisasikan diri mereka kepada masyarakat jauh-jauh hari sebelum diadakannya pemilu legislatif.

\section{Kesimpulan}

Berdasarkan hasil wawancara terhadap Mudzakkir Ali Djamil dan Mukhlis Yusuf, maka peneliti menarik kesimpulan bahwa strategi komunikasi politik yang dilakukan team bertumpu pada sosok figur, penggunaan alat kampanye, sosial media, dan lain sebagainya merupakan faktor pendukung seseorang.

Bagi caleg yang tidak memenangkan pemilu legislatif, team yang dibentuk kurang melakukan pengorganisasian secara maksimal, terutama dalam penggunaan sosial media oleh karena itu perlu adanya penataan kembali personil di internal partai agar dikemudian hari team yang dibentuk lebih paham mengenai strategi komunikasi.

Media, baik itu media massa maupun sosial media merupakan bagian besar daripada komunikasi politik. Karena media dapat mempengaruhi pemikiran-pemikiran khalayak terhadap apa yang dapat ia sampaikan. Meskipun media memang benar-benar dapat mempengaruhi pemikiran khalayak, namun ada sebuah teori yang mengatakan bahwa khalayak itu bersifat pasif atau hanya mengikuti apa yang sudah ada. Namun akhirnya teori tersebut dipatahkan dengan teori-teori yang lain yang dihasilkan melalui penelitian terhadap tindakan masyarakat. Oleh karena itu teori dalam komunikasi politik mengalami perkembangan sesuai dengan penelitian dan penemuan para ahli terhadap tingkah laku khalayak

\section{DAFTAR PUSTAKA}

Alfian. 1993. Komunikasi Politik dan Sistem Politik Indonesia. Jakarta: Gramedia

Almond, Gabriel dan G Bingham Powell Jr. 1966. Comparative Politics: A Development Approach. Boston: Little Brown

Arifin, Anwar. 2003. Komunikasi Politik: Paradigma- Teori-Aplikasi-Strategi dan Komunikasi Politik Indonesia. Jakarta: BalaiPustaka 2006. Pencitraan Dalam Politik (Strategi Pemenangan Pemilu Dalam Perspektif Komunikasi Politik). Jakarta: Pustaka Indonesia

Blumer, Herbert. 1969. Symbolic Interactionism: Perspektif and Method. New Jersy: Harper and Row

Boyd, D. M, Ellison N. B. 2007. Social Network sites: Definitions, History, and Scholarship. Journal of Computer-Mediated Communications: Sosial Media

Cangara, Hafied. 2009. Komunikasi Politik: Konsep, teori, dan Strategi. Jakarta: RajaGrafindoPersada.

Eriyanto. 2002. Analisis Framing: Konstruksi, Ideologi, dan Politik 
Media. Yogyakarta: LKiS Yogyakarta.

Everett M, Rogers. 2003. Communication Technology: The New Media in Society. New York: The Free Press

Firmanzah. Marketing Politik. 2007. Jakarta: Yayasan Obor Indonesia

Jefkins, Fank. 1997. Periklanan. Erlangga: Jakarta.

Kasali, Rhenald. 1995. Manajemen Periklanan: Konsep dan Aplikasinya di Indonesia, Jakarta: Pustaka Utama Grafiti

Maswadi Rauf. 1993. Indonesia dan Komunikasi Politik. Jakarta: Gramedia

McLuhan, Marshall. 1964. Understanding Media: The Extension of man. New York: McGraw-Hill

Mirabito, Michael M, Morgenstern, Barbara L. 2004. The New Communications Technologies: Applications, Policy, and Impact. USA: Focal Press

Nimmo, Dan. 1989. Komunikasi Politik: Komunikator, Pesan dan Media (Edisi Terjemahan oleh Tjun Surjaman). Bandung: PT. Remaja Rosdakarya

Ruben, Brent D. 2006. Communication Year Books 2. New Jersy: ICA

Shannon and $\mathrm{W}$ Weaver. 1957. The Mathematical Theory of Cmmunication. Urbana University of Illinois Press

Straubhaa, J. Rose \& Davenport L. 2012. Media Now: Understanding Media, Culture, and Technology (seventh edition), Boston: Wadsworth

Williams dan Sawyer, Using Information Technology: A Practical Introduction to Computers and Communication, (London: Career Education, 2003)
Jurnal

Hidayat, Dedy N. 1999. "Paradigma dan Perkembangan Penelitian Komunikasi." Jurnal Ikatan Sarjana Komunikasi Indonesia. Vol. 3. April. (24 November 2014)

\section{Website}

Efendy, Naibaho. Iklan Politik, http://efendynaibaho.wordpress.c om/2008/11/28/iklan-politik-2/, diakses tanggal 23 November 2014

Istiyani, Pratiwi. Hubungan Antara Iklan Partai Politik di dengan Sikap Pemilih pada Pemilu 2009, http://etd.eprints.ums.ac.id/4795 /1/F100040087.PDF, diakses tanggal 23 November 2014

http://www.academia.edu/6871925/Ana lisi_Strategi_Komunikasi_Politik_C aleg_Hanura_Menjelang_Pileg_201 4, diakses tanggal 23 November 2014

http://commsciencegroup4.blogspot.com /2012/10/teori-komunikasilasswell.html, diakses tanggal 23 November 2014

http://deviapriyanti158.blogspot.com/20 12/03/teori-teori-dalamkomunikasi-politik.html, diakses tanggal 23 November 2014

https://www.facebook.com/media/set/? set $=a .472017769524730 .110363$. $472005732859267 \&$ type $=1$, diakses tanggal 23 November 2014 